\title{
WELLBEING CONDITION OF INTERNATIONAL MIGRANT WORKERS FROM INDONESIA WHO WORKED IN MALAYSIA: STUDY ON INTERNATIONAL MIGRANT WORKERS FAMILY IN KRANGKENG SUB-DISTRICT INDRAMAYU REGENCY WEST JAVA PROVINCE INDONESIA
}

\author{
Dwi Yuliani \\ Bandung Polytechnic of Social Welfare (Poltekesos), Ir. H. Juanda Street (Dago), No. 367, \\ Bandung, dwi_stks@yahoo.co.id \\ Uke Hani Rasalwati \\ Bandung Polytechnic of Social Welfare (Poltekesos), Ir. H. Juanda Street (Dago), No. 367, \\ Bandung, hanirasalwatiuke@gmail.com
}

\begin{abstract}
The industrial revolution 4.0 has human resources that move between Indonesian workers to Malaysia. This research was conducted to find an understanding of the wellbeing condition of families of Indonesian international migrant workers who work in Malaysia. The research was conducted using quantitative descriptive method. The research respondents were 71 families of international migrant workers. Data collection techniques used questionnaires. Data analysis techniques used descriptive statistical analysis.The results showed that the problems faced by families of international migrant workers from Indonesia working in Malaysia included; (1) disruption of the fulfillment of husband / wife's love needs; (2) disruption of family economic needs; (3) disruption of the care function of children under five years of age (toddlers); (4) the disruption of the fulfillment of children's needs. The efforts made by families of international migrant workers from Indonesia who worked in Malaysia in overcoming their problems include; (1) resigned; (2) asking for large family assistance; (3) forgetting for a better future; and (4) trying to work to find additional income. The result of research on the psychosocial condition of family indicated; (1) families feel anxious in living life; (2) loneliness in living life; (3) difficulty sleeping; (4) anxiety; (4) more irritable and lose patience; (5) often sad; (6) concentration is disrupted when carrying out daily activities; (7) low self-esteem when meeting relatives; and (8) low self-esteem when interacting with neighbors / environment.Related to the socio-economic condition of the families of international migrant workers, the result showed that; (1) the participation of family members in participating in activities in the local environment is low; (2) the fulfillment of family members' food needs is fulfilled; (3) fulfillment of family member's clothing requirement is fulfilled; (4) increase of assets and family ownership is no change; (5) meeting the needs of the social environment and family residence is less fulfilled; (6) meeting the health needs of family members is less fulfilled; (7) the fulfillment of family members' education needs is less fulfilled. Recommended programs through the formation of a Self Help Group.This Self Help Group is a collection of various families of international migrant workers working in Malaysia. In its implementation, this Self Help Group serves as a container and means of families of international migrant workers to experience various experiences in handling problems faced by their families.
\end{abstract}

Keywords:

Wellbeing, International Migrant Worker, Family 


\section{INTRODUCTION}

Globalization has a huge impact on the economic development of a country. The world's population is moving away from the country to other countries that offer higherpaying jobs. Malaysia as a neighboring country of Indonesia is a destination for Indonesian citizens to find work. Malaysia needs workers in the informal sector on the other hand Indonesian citizens need jobs with higher wages.

High economic development in a country has pushed wages and working environment conditions to a higher level in the country. The acceleration of economic development in a country will increase the need for a certain amount of labor. In general, the demand for trained workers in a developed country will be fulfilled from other developed countries. On the other hand, the demand for untrained labor is imported from developing countries. Workers from developed countries are often not interested in jobs that are under their low-paying category. Meanwhile, economic difficulties, the low employment and low wages in developing countries encourage people to seek their fortunes to a more advanced country even without the skills, preparations and working documents necessary to become international migrant workers. Most of the international migrant workers from developing countries are driven by wages that are relatively higher than the wages earned in the country of origin.

The existence of international migrant workers, on the one hand, will create problems such as the deprivation of human rights, physical and psychological violence and minimal protection. In addition, it raises issues related to the abandoned family of migrant workers. The average of even the majority of households of international migrant workers is a mess (Mulyana, 2016). Furthermore, Mulyana (2016) argues that there are two reasons why the families of international migrant workers are not harmonious; first, husband or wife as a life partner cheating. Second is concerning the issue of money shipment. Remittances from overseas workers often turn into domestic disputes. Women who work overseas, parents or relatives of women request money to be sent to their families or parents. However, the husband wants to be sent to the person concerned.

Data in the Indramayu regency Religious Court West Java Indonesia (2016) showed that there are approximately 300 cases of divorce for every month, and most carried out by a woman who became an international migrant workers (Harlan, 31.07.2017). Data from the Cirebon Regency Religion Court (2011) also stated that out of 611,526 families in Cirebon - Indonesia, 6,156 couples had divorced both divorce and divorce throughout 2011. Of the total the divorced couple, $80 \%$ are couples one of whom goes to international migrant worker (Pikiran Rakyat, 8/2/2012).

On the other hand, it is undeniable that the deployment of international migrant workers generate significant money for the family of international migrant workers are concerned. Apart from the management of international migrant workers abroad rightly or wrongly, it is evident that migrant workers have become foreign exchange heroes for the Indonesian people. The existence of international migrant workers is able to drive the economy in the village where international migrant workers originate. Migrant workers send their wages to repair houses to buy rice fields, help with the cost of education for their family members. The existence of 
international migrant workers gives added value to their families.

In 2015 , the existence of international migrant workers contributed to foreign exchange for Indonesia as much as 82 trillion. In 2016 there were 70,000 international migrants in Malaysia which through outsourcing of at least 2.2 million international migrants. However, there were only 1.2 million international migrant workers, the rest were illegal. International migrant workers working more than 8 hours a day are paid 300 to $500 \mathrm{RM}$ (Malaysian Ringgit) or equivalent to 1.2 million - 1.5 million rupiah per month. The driving force of Indonesian citizens into international migrant workers in Malaysia is to improve the welfare of their families in Indonesia. Economic difficulties, lack of employment, and low wages in Indonesia encourage Indonesian citizens to go to Malaysia to become international migrant workers in the hope of improving their family's social economy in Indonesia.

In this paper, family wellbeing refer to family conditions in housing, income and wealth, jobs and earnings, social connections, education and skills, environmental quality, civic participation and governance, health status, subjective wellbeing, individual security, work and life (OECD, 2017). On the other hand, Fox (1974) sees the understanding of wellbeing from economic perspectives where wellbeing is associated with the amount of income of an individual. Next, Bubloz, Eicher, Evers and Sontag (1980) also look from an ecological perspective. According to them, wellbeing is seen as an environment that provides adequate resources in dealing with human needs including the units needed by humans. On the other hand, Murrel and Norris (1983) saw the wellbeing of "community psychology perspective". This perspective considers wellbeing as "goodness of fit" between individuals and the environment in a community. The emphasis of this perspective is on the "provision of resourcess" as a way to improve the wellbeing of individuals and families in a community.

Chambers (1997 suggested that wellbeing as a"social well being" includes social, mental, psychological, and material. He stated that the state of wellbeing includes the following:

1. Having a decent degree of life, enough access to basic social services, security and freedom, and capable of self-actualization and self-creation.

2. Security in livelihoods. With the existence of livelihood, it can be sufficient in fulfilling food and money needs, income security so that it can reach basic social services.

3. Have skills as a basis for supporting livelihood security. These skills can be obtained through the process of learning, practice, training and education for the purpose of a better life in the future as a prerequisite in improving welfare.

4. The presence of Justice. Justice includes human rights and gender justice

5. The existence of sustainability. This means that the conditions as mentioned above (state of well-being, livelihood security, skills, justice) must be sustainable to future generations.

The existence of international migrant workers from Indonesia who work in Malaysia, and the description of the condition of family wellbeing described above, is the basis for conducting research on the family wellbeing conditions of Indonesian migrant workers who work in Malaysia. This research 
was conducted to obtain an in-depth and comprehensive picture of the family wellbeing of Indonesian migrant workers who work in Malaysia.

\section{Objective of the Study}

This research is aimed to obtain a thorough understanding of the wellbeing condition of the families of international migrant workers from Indonesia who work in Malaysia. Particularly to gain a thorough understanding of the wellbeing conditions of the families of international migrant workers from Indonesia who work in Malaysia, including; (a) the problems facing the family; (b) family psychosocial condition; and (c) family socioeconomic conditions. In addition, this research is also conducted to understand coping strategy of family of international migrant workers from Indonesia who work in Malaysia in handling the problem.

\section{METHOD}

The research was conducted using quantitative descriptive method to describe the wellbeing condition of Indonesian migrant worker families who work in Malaysia. Data collection techniques are conducted through interviews based on research instruments that have been prepared previously. The research population is an international migrant worker family whose mother works in Malaysia in Krangkeng Sub-district, Indramayu Regency, West Java Province. The reason for choosing the location is because there is a family population of international migrant workers whose family members work in Malaysia under a work contract in Malaysia. Number of respondents as many as 71 families of international migrant workers working in Malaysia Determination of the number of respondents based on quota sampling. Data analysis used descriptive statistic analysis by looking at concentration symptoms.

\section{FINDINGS}

\section{The Problems Faced by International Migrant Workers' Families}

The results showed that the problems faced by the families of international migrant workers from Indonesia who work in Malaysia include; (1) disruption of the fulfillment of the needs of the affection of husband / wife (43.37\%); (2) disruption of the fulfillment of the family's economic needs (26.67\%); (3) disruption of the care function of children under five years of age (toddlers) (21.05\%); (4) disruption of the needs of primary school age children (23.67\%); and (5) disruption of the needs of secondary school age children $(16.47 \%)$. For more details, the picture can be seen in the following graph:

\section{a. Psychosocial Condition of International} Family

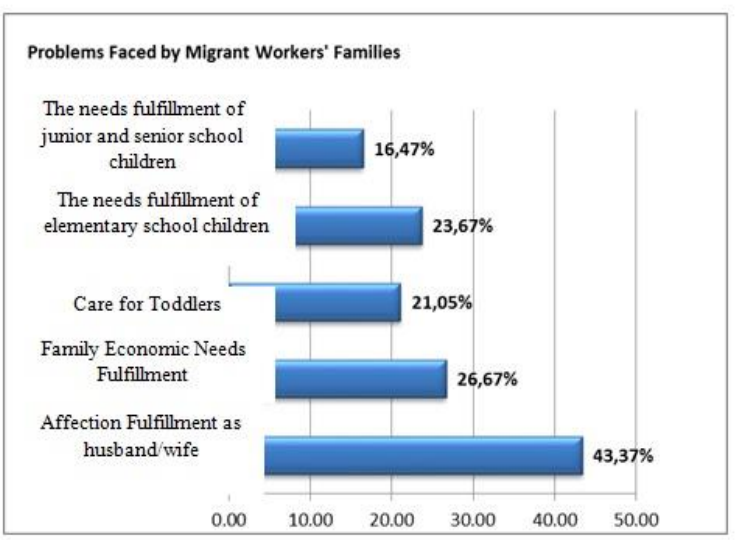

Graph 1. Problems Faced by Migrant Worker's Families

The results of research on family psychosocial condition indicated; (1) families feel anxious in life (43.23\%); (2) loneliness in life $(54.67 \%)$; difficulty sleeping (27,67\%); (4) anxiety $(39,43)$; (4) more irritability and loss of patience $(28.96 \%)$; (5) often sad $(31.64 \%)$; 
(6) disrupted concentration when carrying out daily activities (23.65\%); (7) low selfesteem when meeting with relatives
(27.05\%); and (8) low self-esteem when interacting with neighbors / environment $(63.43 \%)$.

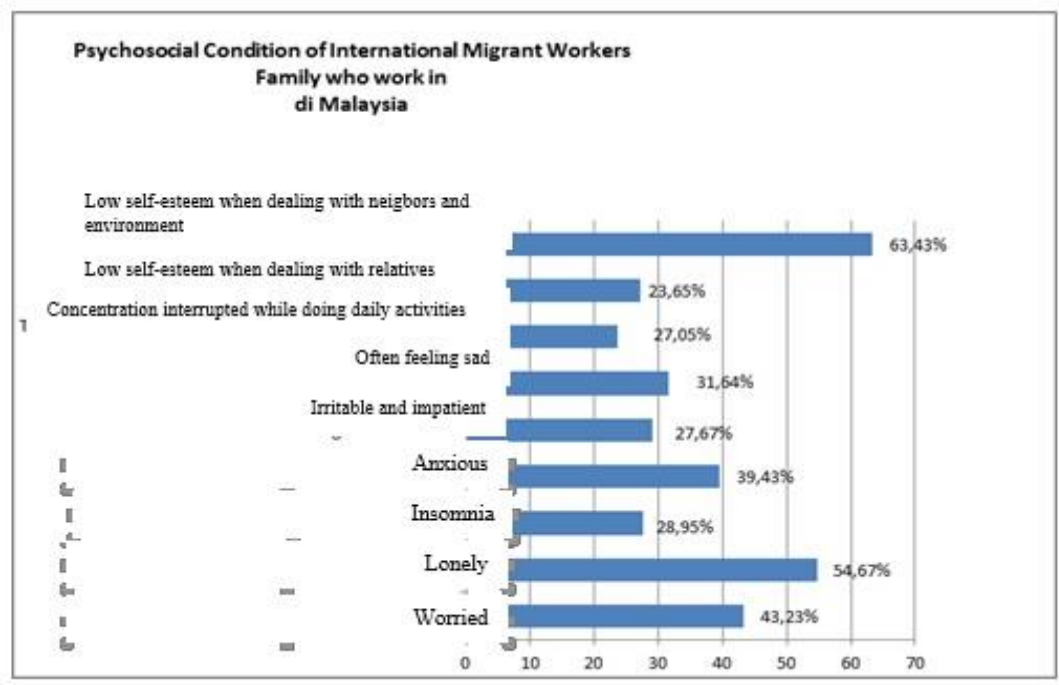

Graph 2. Psychosocial Condition of International Migrant Workers Family who work in

\section{Malaysia}

The results also showed that the

(31.17\%); (4) often sad (33.33\%); psychosocial conditions of family children;

(1) children feel anxious in life $(32.14 \%)$; disrupted concentration when carrying out (2) children feel lonely in life $(54.67 \%)$; (3) daily activities (37.15\%); and (5) low selfchildren are anxious to think of parents esteem when meeting with friends (26.17\%).

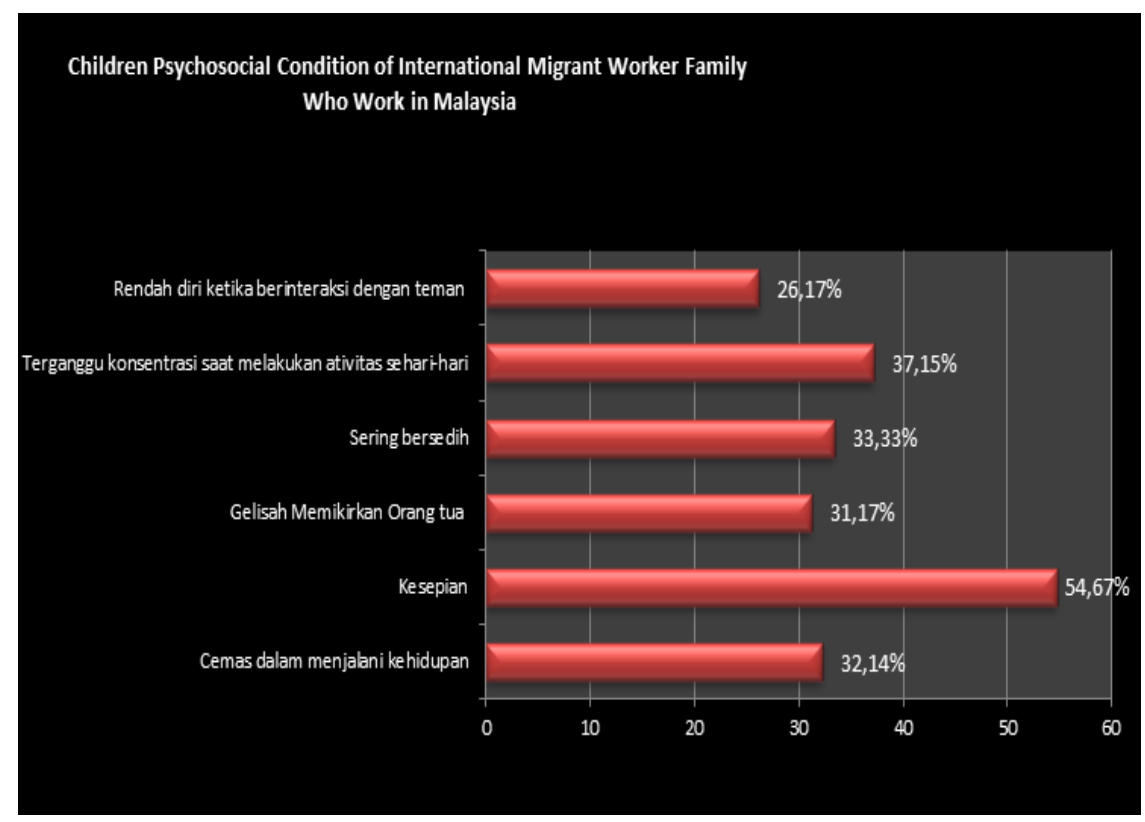

Graph 3. Children Psychosocial Condition of International Migrant Workers Family who work in Malaysia 


\section{b. Socio-economic Condition}

Related to the socio-economic condition of the families of international migrant workers, the Results showed (1) the participation of family members in participating in local family activities is low $(87.16 \%)$. The reason for not participating in environmental activities is because there is no free time or busy. (2) fulfillment of family member's food requirement is fulfilled $(97,26 \%)$; (3)

\section{c. Coping Strategy}

The findings of the research found that coping strategy of international migrant workers from Indonesia working in Malaysia in adressing the needs of the husband/wife's affection in terms of fulfillment of family member's clothing requirement is fulfilled $(95,89 \%)$; (4) increase of assets and family ownership is no change $(67.12 \%)$; (5) meeting the needs of the social environment and family residence is less fulfilled $(67.12 \%)$; (6) the fulfillment of family members' health needs is less fulfilled (76.71\%); and (7) fulfillment of family member's education need is less fulfilled $(67,12 \%)$

intercourse (sex) include; (1) resigned (35.56\%); (2) carrying out other activities $(26,71 \%) \%)$; (3) looking for a replacement partner $(7.53 \%)$; (4) forgetting for a better future $(21,23 \%)$ (5) do not need $(8.22 \%)$; and $(6)$ others $(2,74 \%)$.

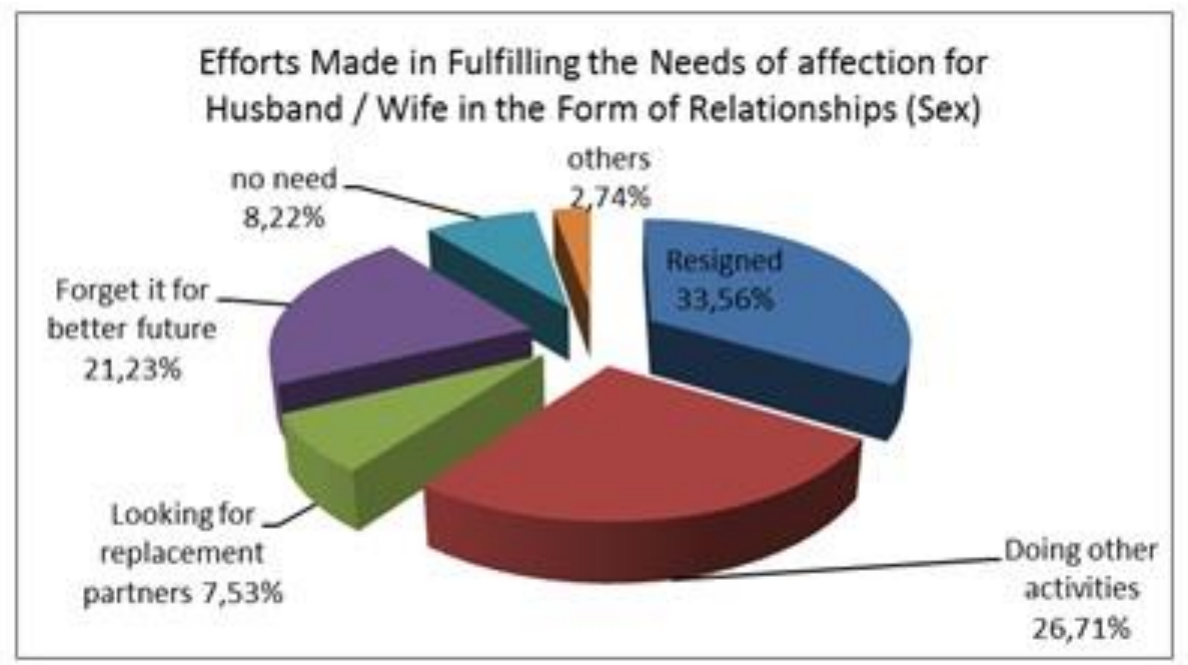

Graph 4. Efforts Made in Fulfilling

the Needs of affection for Husband / Wife in the Form of Relationships (Sex)

Coping strategy in meeting the family's Economic needs include; (1) resigned $(38.36 \%)$; (2) asking for big family assistance (25.34\%); (3) asking for help from other parties to help him / her in debt (7.53\%); (4) Working to earn additional income (18.49\%); mortgaging goods $(8.22 \%)$; and (6) others
$(2.05 \%)$. Coping strategies in childcare include; (1) resigned (38.36\%); (2) trying to fulfill it even without a spouse $(33.56 \%)$; (3) entrust to the teacher, or a large religious or family figure $(17.53 \%)$; (4) entrusted to the Social Welfare Institution (Social Institution) (18.49\%); and (5) others $(2.05 \%)$ 


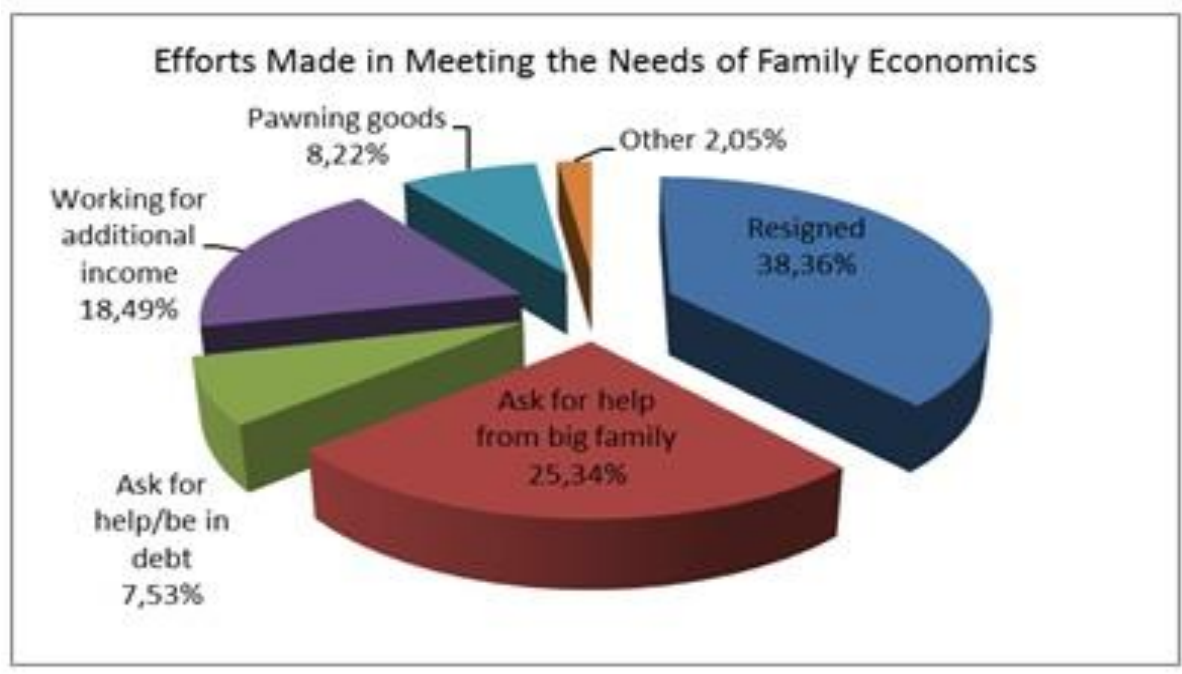

Graph 5. Efforts Made in Meeting the Needs of Family Economics

Coping strategy in handling the psychological impact of family members include; (1) resigned (43.84\%); (2) seeks to understand and solve $(29.45 \%)$; (3) trying to understand and solve it self $(11,64 \%)$, giving understanding to family member $(13,70 \%)$ not one respondent claimed to ask for professional help to finish it.

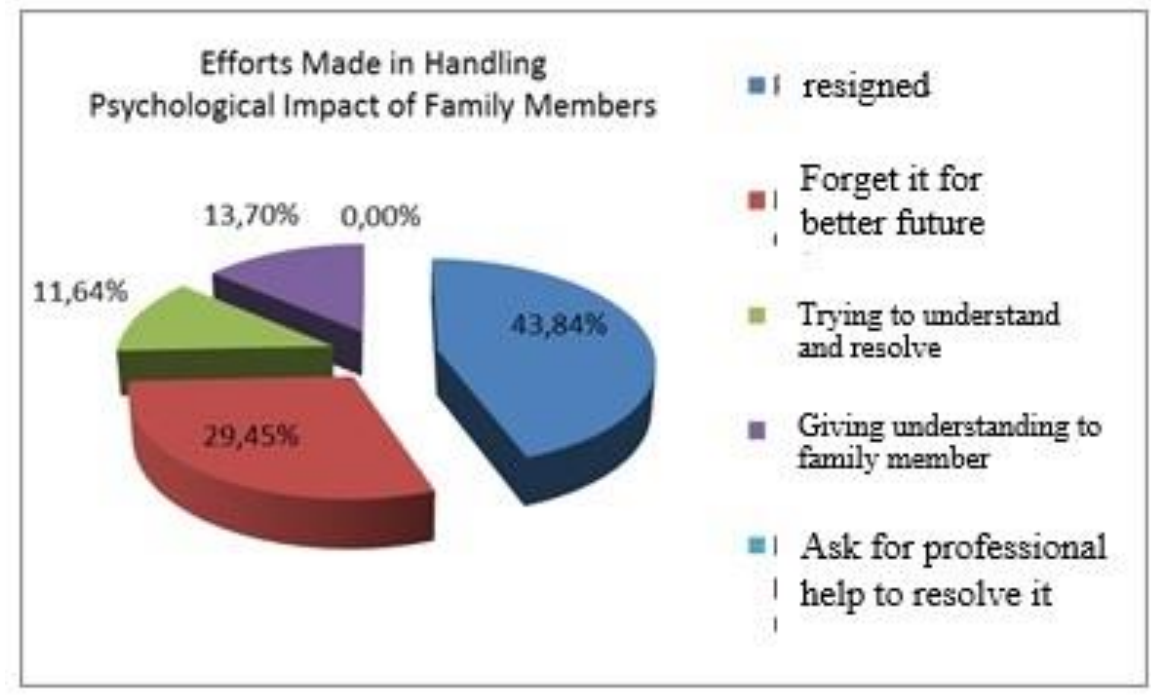

Graph 6. Efforts Made in Handling Psychological Impact of Family Members

Coping strategy in meeting the other parties to help him / her in debt educational needs of family members (7.53\%); (4) Working to earn including; (1) resignation (45.89\%); (2) asking for the help of extended family additional income $(18.49 \%) ;(5)$ mortgaging (21.89\%); (3) asking for help from goods $(4.79 \%)$; and (6) others $(1.37 \%)$. 


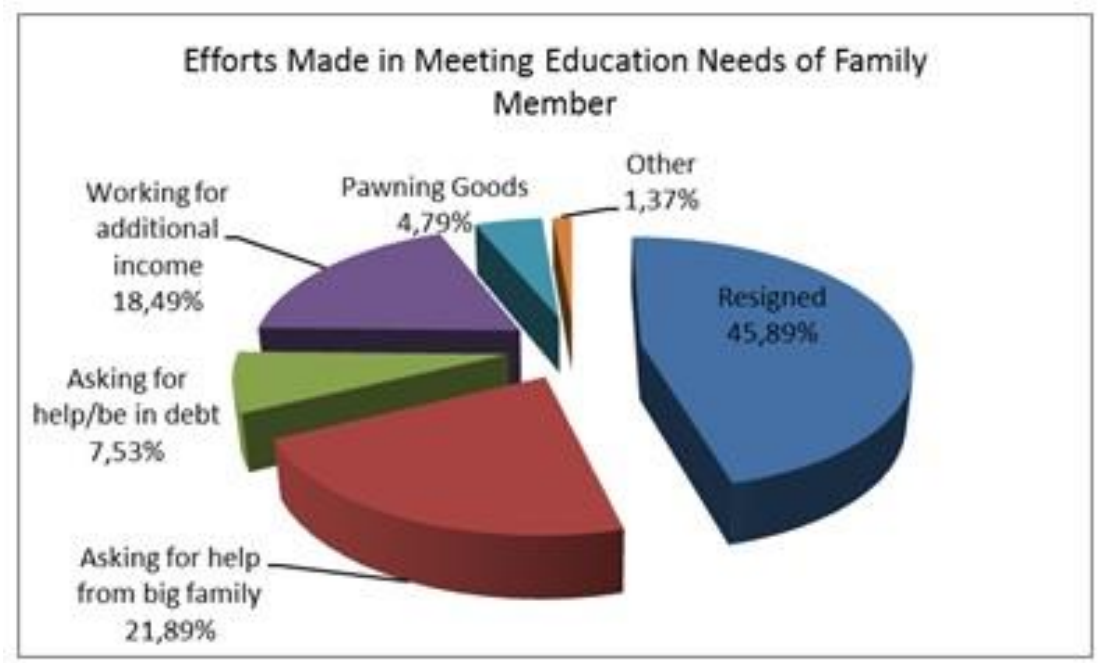

Graph 7. Efforts Made in Meeting Education Needs of Family Member

Coping strategy in meeting the health needs of family members include; (1) resignation (51.37\%); (2) asking for help from large families (31.00\%); (3) asking for help from others to help / owe (8.22\%); (4) mortgaging goods (4.79\%); and (5) selling goods / assets $(4.79 \%)$

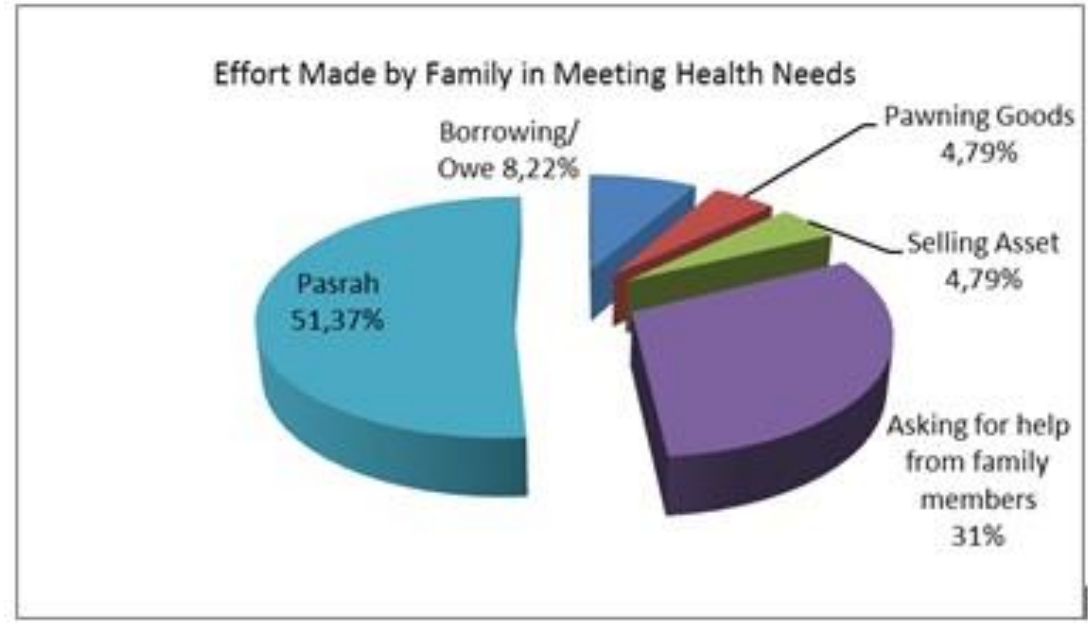

Graph 7. Efforts Made by Family in Meeting Health Needs

\section{DISCUSSION}

International migrant workers from Indonesia who work in Malaysia are defined as citizens of Indonesia who work in Malaysia for a certain time with the aim to find work to improve the welfare of his family. Most of the international migrant workers from Indonesia who work in Malaysia are mostly women, girls or young women and adult women or those who have a family. However, there are also men. These international migrant workers, in Indonesia are more popularly known as TKI (Indonesian Workers) or also known as cross-country migrant workers or international migrant workers.

The pull factor for the emergence of international Indonesian migrant workers 
working in Malaysia due to high economic development in Malaysia has pushed wages and working conditions to a higher level in the country. The acceleration of economic development in Malaysia will increase the demand for labor in a certain amount. In general, demand for trained workers in Malaysia will be met from other countries including Indonesian citizens.

On the other hand, the driving factor for Indonesian citizens to work in Malaysia to become international migrant workers is to improve the welfare of their families in Indonesia. Economic difficulties, lack of employment, and low wages in Indonesia encourage Indonesian citizens to go to Malaysia to become international migrant workers in hopes of increasing their family's socio-economic status in Indonesia. Improving the welfare conditions (wellbeing) of families of Indonesian migrant workers who work in Malaysia which are marked by; (1) increased ability to cope with family problems; (2) increased family psychosocial condition; (3) the fulfillment of the socio-economic needs of the family.

However, research result showed that with the workings of a family member, husband or wife becomes an international migrant workers to Malaysia led to problems in the family. Family problems include; (1) disruption of the fulfillment of husband / wife's love needs; (2) disruption of family economic needs; and (3) disruption of care functions and fulfillment of children's needs.

This condition is in accordance with the opinion of Khairuddin (1985) about family functions. Problems that arise due to the absence of the role of one family member (father / husband or wife / mother) who go abroad to become international migrant workers are as follows;

1. Loss of biological function. The family is the birthplace of children. The biological function of parents is to give birth to their children. This function is the basis of existence and sustainability of a society. Furthermore, parents (father / husband or wife / mother) should have a role in providing life opportunities to its members. The role shown in providing this opportunity for life must be followed by the behavior of providing food, clothing and getting used to a healthy way of life for their children. The problem is that if one parent (father / husband or wife / mother) goes abroad to international migrant worker within a period of less than two years then one of the roles they display will be lost. If the father / husband or wife / mother works as an international migrant worker, the biological function of the family will be disrupted. This condition causes the family status to become incomplete. As a result there will be an imbalance in the family structure. When this condition drags on, it will lead to other problems in the family, such as the occurrence of partner abuse (marry again without the knowledge of wife or husband), the emergence of jealousy that ultimately is not impossible to cause conflict and divorce.

2. Interrupted affection function. In the family usually occurs a social relationship filled with affection and affection or affection. Relationship affection occurs between children with parents, husband with wife or sister with brother. This affection relationship grows 
as a result of the relationship of love that becomes the basis of marriage, so that the relationship of brotherhood, friendship, equality and common habits is born. However, if one family member is very important, namely the father / husband or wife / mother leaving their role because of working abroad, this affective function will be disrupted. Children will feel that nothing can protect, who can give love, who can pay attention and be consulted regarding the problems they face.

3. Disruption of socialization function. The function of socialization shows a role in shaping the child's personality. Through social interaction in the family, children learn patterns of behavior, attitudes, beliefs, ideals, values and self-declared as social beings. Parents (father or mother) have a duty and have a role in instilling values and norms that apply in the family and the environment (community) to prepare and deliver children in community life. The problem is that if one of the parents (father or mother) goes abroad to become an international migrant worker, this condition will affect his / her role in performing the socialization function. The absence of parental (father or mother) parenting that provides education about attitudes and behaviors that are in accordance with the norms and values of society, the child becomes less understanding that will eventually lead to attitudes and patterns of behavior that violate the norms and values that exist in the community. In other words, the child will have a behavior pattern that deviates from the values and norms of society.
In relation to psychosocial conditions, the results of the research showed that working with one family member, husband or wife to become an international migrant worker to Malaysia had an impact on the emergence of family psychosocial problems. Various psychosocial issues include; (1) families feel anxious about living their lives; (2) loneliness in living life; (3) difficulty sleeping; (4) nervous; (4) more irritability and loss of patience; often sad; (6) disrupted concentration when carrying out daily activities; (7) low self-esteem when meeting relatives; and (8) low self-esteem when interacting with neighbors / environment. The loss of mothers or fathers who work as international migrant workers to Malaysia has an impact on the emergence of psychosocial problems in children. Various psychosocial problems in the families of international migrant workers working in Malaysia include; (1) the child feels anxious about living a life; (2) children feel lonely in life; (3) uneasy children think of parents; (4) often sad; (5) disrupted concentration when carrying out daily activities; and (5) inferiority when meeting friends.

The impact of the existence of Indonesian migrant workers working in Malaysia on the psychosocial condition of the families of international migrant workers is contrary to the functioning of families in providing protection and affection for their members. The function of the family is to protect and provide psychological serenity to its members (Khairuddin, 1985, Hurlock 1998). Families also have affection and socialization functions. In this context, through the family, members will gain effective affection, protection, and social 
interaction to meet the individual needs of their members. Through social interaction in the family, children learn patterns of behavior, attitudes, beliefs, ideals, values and self-declared as social beings. Parents (father or mother) have a duty and have a role in instilling values and norms that apply in the family and the environment (community) to prepare and deliver children in community life. The problem is that if one of the parents (father or mother) goes abroad to become an international migrant worker, this condition will affect his / her role in performing the socialization function. The absence of parental (father or mother) parenting that provides education about attitudes and behaviors that are in accordance with the norms and values of society, the child becomes less understanding that will eventually lead to attitudes and patterns of behavior that violate the norms and values that exist in the community. In other words, the child will have a behavior pattern that deviates from the values and norms of society.

The research results showed the presence of international migrant workers from Indonesia who work in Malaysia has only an influence on the fulfillment of food and clothing needs of the family. The presence of Indonesian migrant workers working in Malaysia has no impact on the fulfillment of social needs, increased ownership of family and housing assets, health fulfillment, and family education. Referring to the family category proposed by Grown and Sebstad (1989), the families of international migrant workers from Indonesia working in Maaysia are categorized as family for need for survival, and the need for security family category. In that context, the employment of a family member of either mother or father to Malaysia becomes an international migrant worker only to survive and / or just to secure the basic needs of food and clothing.

Referring to Mulyana's opinion (2016), the results of this research indicated that the presence of international Indonesian migrant workers working in Malaysia does not have a positive impact on the wellbeing condition of the family, and even the majority of international migrant workers from Indonesia who work in Malaysia are in disarray. There are two messy reasons for the families of international migrant workers; first, husband or wife as a life partner cheating. Secondly concerning the issue of money shipment. Remittances from work in Malaysia are often a family dispute. Women who work overseas, parents or relatives of women request money to be sent to their families or parents. However, the husband wants to be sent to the person concerned.

In addressing the problems arising from one of the family members, both wife and husband becoming international migrant workers to Malaysia, various efforts are made by family members in overcoming the impact of the loss of one of his family members. However, the family coping strategy is not optimal and not effective in dealing with the negative impact of the loss of one family member. Resignation, seeking other partners, forgetting for a better future, pawning goods, selling assets and so on meruakan coping strategy that the family did in addressing the negative impact of the existence of migrant workers iternasional working in Malaysia. In this context, coping strategy carried out by the families of 
international migrant workers will create new problems for their families. Therefore, it is necessary to formulate an alternative program to overcome the negative impact of the existence of international migrant workers from Indonesia who work in Malaysia for their family in Indonesia.

The role of a wife / mother or father / husband in a family plays an important role. The wife / mother has a role as a companion to the husband, as a caregiver and educator of his children. Instead father / husband has a role as a leader in the family, educators and patrons for members of his family. In this regard, the departure of a wife / mother or father / husband working overseas as an international migrant worker will have an impact on the integrity and function of the family.

\section{CONCLUSION}

The existence of international migrant workers from Indonesia who work in Malasyia is an effort to improve the condition of wellbeing of his family. However, the presence of international Indonesian migrant workers working in Malaysia does not have a positive impact on improving the wellbeing conditions of his family. In the socio-economic aspect, the presence of international migrant workers from Indonesia working in Malaysia has only a positive impact on increasing the fulfillment of food and clothing needs of their families only. The presence of international Indonesian migrant workers working in Malaysia does not have a positive impact on the fulfillment of social needs, increased ownership of family assets, the fulfillment of health needs, and the fulfillment of the educational needs of his family. On the other hand, the presence of Indonesian migrant workers working in Malaysia has an impact on the emergence of family problems, and the emergence of family psychosocial problems.

It is recommended that there be an effort to address the impact of the presence of international migrant workers from Indonesia who work in Malaysia on their condition. The recommended program is through the establishment of the Self Help Group. This Self Help Group is a collection of various families whose family members (wife / husband or one of its members) work as international migrant workers in Malaysia. After the formation of Self-Help Groups, further assistance from professionals or officers with knowledge, skills in family handling, and child care, and empowerment and family development are required. In its implementation, this Self Help Group serves as a container and means of families of international migrant workers to share experiences and advice on handling the problems they face.

\section{REFERENCES}

Berns, R. RM. 1997. Child Family, School, Community, Socialization and Support. 4th.ed. Philadelphia. Harcout Brace College.

Boss, P.G, Doherty, W.G Larossa. R. Schumm, W. R. Dan Steinmetz. S.K. 1993. Sourcebook of Family Theory and Methode. A Contextual Approach. Plenum Press. New York.

Cousheld, Veronica dan Orme, Joan. 1998. Social Work Practice. MacMillan Distribution. London

Creswell. 2014. Research Design : Pendekatan Metiode Kualitatif, Kuantitatif dan Campuran. Pustaka Pelajar. Yogyakarta

Dubowitz \& De Panfillis, Diane. 2000 
Handbook For Child Protection Practice. Thousand Oaks. Sage Publication. Inc. London

Inkeles, A. 1965. Participant Citizenship In Sixth Developing Countries. American Political Science Review.

Irawan Soehartono. 2011. Metode Penelitian Sosial. PT Remaja Rosdya Karya. Bandung

Jong, De dan Fawcett, 1981. Migration Decision Making. Pergamon Press. New York.

Khaerudin, 2002. Sosiologi Keluarga. Liberti. Yogyakarta

Mulyana, Ichwan 2016. Rumah Tangga TKI Mayoritas Berantakan. Pikiran Rakyat: 8 Pebruari 2012.

Newman, Barbara M \& Philip R Newman. 2006. Development ThrOugh Life. A Psychosocial Approach. Thomson Wordsworth. Australia.

Neuman, W Lawrence. 2013. Metodologi Penelitian Sosial: Pendekatan Kualitatif dan Kuantitatif. Edina $\mathrm{T}$ Sofia (Penterjemah). PT. Indeks. Jakarta

Nursid Sumaatmaja, 1986. Perspektif Studi Sosial. Alumni. Bandung

Rafael, Engel J, Russell, Schutt K. 2010. Fundamentals of Social Work Research. SAGE Publication Ltd. London

Steinberg, L. 1993. Adolescence. Mc. Graw-Hills. New York

Suharto, Edi 2003. Kemiskinan dan keberfungsian sosial : studi kasus rumah tangga miskin di Indonesia. Bandung : Departemen Sosial RI - Sekolah Tinggi Kesejahteraan Sosial.

Sunarti, Euis. 1997. Hubungan Antara Tekanan Ekonomi dan Mekanisme Coping

Dengan Kesejahteraan Wanita Pemetik Teh. Jurnal Keluarga. IPB

Syaefullah, Djadja. 1999. Pemikiran Kontemporer Administrasi Publik :Perspektif Manajemen Sumber daya Manusia Dalam EraDesentralisasi,Bandung: LP3AN Fisip UNPAD.
Turner, Francis J. 1978. Psychosocial Therapy. A Social Work Perspective. The Free Press, New York dan Mac Millan, London.

Yaumil, 1994. Pembangunan Kesejahteraan Keluarga : Sebagai Wahana Pembangunan Bangsa. Prisma No. 6-994, LP3ES

Zastrow, Charles. 2000. Introduction to Social Welfare Institution, Social Problems, Services and Current Issues. The Dorsey Press. Illionis . 2006. Social Work With Groups. A Comprehensive Workbook. Thomson Book. Cole. Australia 